\title{
Geloof in die opstanding van Jesus: Barth en Bultmann
}

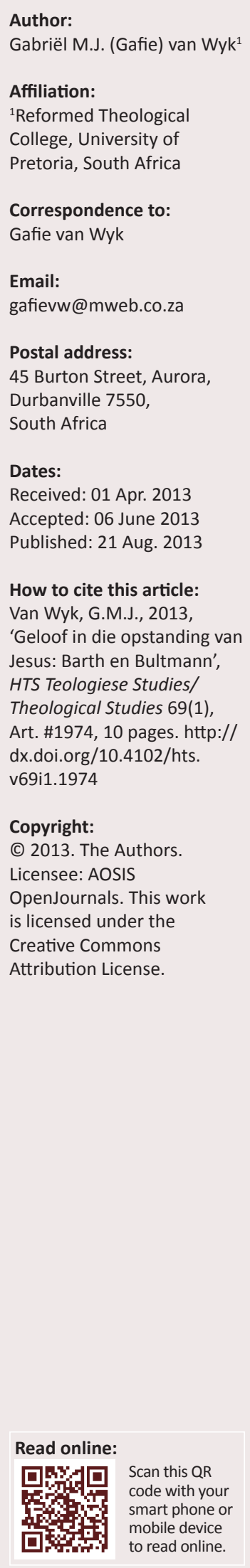

Faith in the resurrection of Jesus: Barth and Bultmann. This article aims to contribute to the understanding of the views of Barth and Bultmann on the interpretation of Jesus' resurrection. It deliberately steers away from the abundance of secondary material available on the subject and focuses on the relevant primary sources with the result that the differences between the two authors come sharp into focus. The fundamental difference between Barth and Bultmann is not that Barth believes that Jesus has truly risen from the grave, but that Bultmann does not believe it. The hermeneutical question about the presence of Jesus Christ, the risen Lord and his work of salvation is the central issue of Christology for both theologians, but this is also the point on which they differ radically from each other. The Auseinandersetzung between Barth and Bultmann indicates how ongoing and intensive theological discourse can benefit the proclamation of the gospel and the church.

\section{Inleiding}

Gerhard Ebeling (1967) skryf teen die agtergrond van die groeiende 'wachsame Sorge um die Reinheit der evangelischen Verkündigung' in die kerk van sy tyd:

Die Gefahren einer Konzentrationsbewegung sind naturgemäss die der Vereinseitigung, Verengung und Abkapselung, eines Strebens nach Sicherung und Unangreifbarkeit, einer Flucht vor der Auseinandersetzung und der Anfechtung.... Dennoch heben sich gewisse Haupttendenzen in mannigfacher Schattierung ab: ein neuer theologischer Dogmatismus und traditionalistischer Konfessionalismus, ein Klerikalismus und Sakrametalismus, eine Simplifizierung durch Drängen auf pietistische Erbaulichkeit oder auch durch Schlagworttheologie, Radikalismus, Bekenntnisrhetoriek usw. (bl. 49)

Die situasie wat Ebeling beskryf, sou tans van toepassing gemaak kon word op die Nederduitsch Hervormde Kerk van Afrika (NHKA). Met die ontslag van prof. Albert Geyser in 1962 het die vermeende stryd teen dwaalleer in die Hervormde Kerk 'n magtige wapen geword in die hand van 'n polities konserwatiewe en teologies behoudende groepering in die Kerk. Vanuit dieselfde groepering klink weer stemme op wat ampsdraers van die Kerk van dwaalleer beskuldig. Omdat die aantygings van dwaalleer waarna hier verwys word, goed gedokumenteer is in kerklike stukke (soos notules van vergaderings), gaan ek nie verder daarop in nie. Die vraag is of, wanneer dit by die verdediging van die evangeliese boodskap kom, daar nie ' $n$ alternatief moontlik is vir die juridiese prosesse van aanklag en verdediging nie? Ek meen die teologiese 'Auseinandersetzung' tussen Barth en Bultmann wat getuig van diepgaande verskille tussen dié twee teoloë, te same beoordeel met Barth se reaksie toe hy deur die kerklike leiers om advies oor Bultmann se teologie genader is, dui ' $n$ moontlike alternatief aan, naamlik voortgaande en indringende teologiese diskoers in diens van die evangelie en die kerk. Die saaklike tema wat op die tafel geplaas word, met die Barth-Bultmann-Auseinandersetzung is die opstanding van Jesus. Soos in die tyd van Barth en Bultmann, is die tema steeds kontroversieel - ook in die Hervormde Kerk. Is dit noodwendig dat radikale teologiese verskille oor hierdie tema tot die verkettering van een groepering moet lei?

Die teologie van Barth en Bultmann en hulle onderlinge gesprek oor teologie kan diepgang aan die eietydse gesprek oor Jesus se opstanding bevorder, indien ons bereid is om grondig - eerder as bloot polemies - opnuut van Barth en Bultmann kennis te neem. Ek gedenk die werk van Barth en Bultmann met die vaste oortuiging dat dit nog nie aktualiteit verloor het nie en dat die wyse waarop hulle oor die saak en met mekaar in gesprek omgegaan het, steeds vir die kerk as voorbeeld kan dien oor hoe teologiese meningsverskille kerklik hanteer kan word. Barth (1953) se opmerkings oor Bultmann in die voorwoord van Die Kirchliche Dogmatik IV/1 beskryf na alle waarskynlikheid nie net sy mening oor Bultmann nie, maar ook die wedersydse verhouding tussen dié twee teoloë. Nadat Barth (1953:ii) uitgespel het dat sy gesprek met Bultmann altyd ter sprake is in sy teologie, skryf hy: 'Ich respektiere ihn, seine Gesinnung, sein Wollen, seine Leistung, und auch den Eifer seiner Schar.' Wanneer hy dan Bultmann se voorbehoude oor sy eie teologie oorweeg het, merk hy op: 
Verplichtend könnten mir seine Vorschläge zur Hermeneutik erst werden, wenn ich überzeugt würde, dass ich bei ihrer Befolgung dasselbe noch freier und wirklich besser sagen könnte. Vorläufig bin ich eben davon nicht überzeugt worden. (Barth 1953:ii)

Barth en Bultmann het oor baie meer sake saamgestem, as waaroor hulle verskil het en die verskille tussen hulle was in 'n hoë mate fyn genuanseerd, juis daarom kon hulle mekaar nooit volkome oortuig oor alle fasette van die interpretasie van Jesus se opstanding nie.

Sowel Barth as Bultmann se teologiese nadenke oor die opstanding is terselfdertyd ook besinning oor die vertrekpunte van teologiebeoefening. Barth en Bultmann is dit eens dat die geloof in Jesus se opstanding nie net ' $n$ tema binne ' $n$ dogmatiese sisteem is nie, maar wel die uitgangspunt en moontlikheidsvoorwaarde van alle Christelike teologie.

\section{Karl Barth (1886-1968)}

Wanneer mens Karl Barth se teologie in oënskou neem, is dit duidelik dat Barth se teologiese werk soos wat dit in sy Kirchliche Dogmatik neerslag gevind het, nie toevallig so omvangryk is nie. Die omvangrykheid van die Kirchliche Dogmatik het met teologiese saaklikheid te make, spesifiek met Barth se oortuiging - wat ook praktiese beslag gekry het in sy werk - dat jy as teoloog bereid moet wees om telkens oor te begin. Soos Barth (1977:129-130) self skryf: 'Theologische Arbeit unterscheidet sich von anderer dadurch [...] jeden Tag, ja zu jeder Stunde neu mit dem Anfang anzufangen.' Barth verstaan natuurlik die Begin, die Aanvang, as die Woord, die vleesgeworde Woord, Jesus Christus. Geen teologiese idee of ideologie kan die plek van Christus inneem nie. Barth se hele teologie gaan daaroor om aan te toon dat Jesus Christus God se vriendelike woord aan die wêreld is. Binne hierdie raamwerk moet sy denke oor Jesus se opstanding aan die orde kom.

Volgens Barth berig die opstandingsvertellings van die Nuwe Testament oor gebeure wat werklik in die geskiedenis afgespeel het. Hy benadruk egter dat hiermee eintlik nog niks gesê is wat waarborg dat ons die berigte reg sal verstaan nie. Ons moet daarvan bewus wees dat ons die Nuwe Testamentiese opstandingsberigte alleen reg kan verstaan wanneer ons in gedagte hou dat die gebeure wat verhaal word, nie op die gebeure as sodanig fokus nie, maar wel op die veronderstelling dat dit oor dade van God handel, wat aan die dissipels die kruisgebeure as heilsgebeure bekend maak. Met die opstandingsboodskap word 'n belofte van lewe dus aan die dissipels en aan die gemeente gegee. Hierdie belofte is die sentrum van die opstandingsverkondiging (Barth 1953:373). Alles wat saaklik verder oor die opstanding berig word, is toeligting van hierdie primêre uitgangspunt.

Die opwekking van Jesus is volgens Barth (1953:330-341) ondubbelsinnig 'n daad van God. Enige moontlike aspek van menslike handeling of wil is van die opwekking van Jesus uitgesluit. Hy stel dat: die Auferweckung Jesu Christi (mit allem, was sie für uns selbst, für alle Menschen impliziert) im Neuen Testament in gleichem Ernst als eine Tat Gottes aufgefasst und verstanden wird wie das ihr vorangehende Kreuzesgeschehen mit seiner Implikation für uns und alle Menschen. (Barth 1953:330)

Die opstanding was nie 'n mirakel wat Jesus geloofwaardig maak nie, maar God se bekendmaking van kennis wat vir die mens verborge en ontoeganklik was. Barth verstaan die opwekking van Jesus as die eintlike, oorspronklike, eksemplariese gestalte van openbaring as sodanig, met ander woorde, die openbaring van God (Barth 1953:332).

Teenoor die kruisiging is die opstanding 'n nuwe selfstandige daad van God (Barth 1953:335). Kruisiging en opstanding is twee onderskeibare en verskillende gebeure. Die opwekking van Jesus is nie net die formele, noëtiese keersy van die kruisiging, wat die betekenis van die kruisiging aan die lig bring nie (Barth 1953:331, 335). Met die opwekking van Jesus antwoord God op sy kruisiging en spreek Hy die oordeel uit dat die weg van die Seun volgens sy wil was. By die opstandigsgebeure gaan dit oor meer as net die kruis (Barth 1953:336). Nou gaan dit oor die toekoms en nie net meer oor die verlede nie. Die opstanding van Jesus Christus is God se oordeel oor en die voltrekking van die kruisgebeure, asook die verkondiging van God se beslissing daaroor. Die opwekking van Jesus is 'n vrye liefdesdaad van God aan die mense, maar tegelyk ook 'n regshandeling wat betrekking het op die weg van Jesus. Die opwekking van Jesus is God se:

richterliche Feststellung, dass Jesu Christi Tun und Leiden nicht ohne, nicht gegen, sondern nach seinem heiligen und guten Willen, und vor Allem: dass es als sein Sterben an unserer Stelle nicht umsonst, sondern gültig, und nicht zu unserem Verderben, sondern zu unserem Heil geschehen sei. (Barth 1953:336-337)

Ons moet egter Barth (1967) op hierdie punt nie eensydig interpreteer nie. Hy benadruk dat daar ook 'n onlosmaaklike band tussen kruis en opstanding bestaan:

Halten wir schliesslich fest, dass die Früchte der Auferstehung Christi in der Hauptsache dieselben sind wie die Früchte seines Todes. Die Auferstehung ist also nichts anderes als die Offenbarung dessen, was uns der Tod Christi verschafft; die Erhöhung offenbart uns den Sinn, das Ziel und die Tragweite der Erniedrigung. (bl. 90)

Daar bestaan dus 'n positiewe samehang tussen Jesus se kruisdood en sy opwekking (Barth 1953:341). Dit is immers een en dieselfde Jesus wat gekruisig is en wat deur God opgewek is. Die dood en opstanding van Jesus is beide dade van God, wat saam en naas mekaar gestalte gee aan die geskiedenis van God met die sondige wêreld. In die omvattende sin van die woord sterf Jesus vir ons en staan Hy ook vir ons op. Die samehang tussen hierdie twee gebeurtenisse verander ons situasie, ons stand en ons hele bestaan, want deur hierdie twee dade word die wêreld met God versoen (Barth 1953:341).

Vir Barth is die vraag na die tydsverhouding tussen kruis en opstanding ook van belang. Weber (1967:214) formuleer die basiese probleem waaroor dit vir Barth gaan soos volg: 'wieso eigentlich Christus für uns "damals" auch Christus für uns 
"heute' sei".' Barth (1953:345) wys ook op Luther se vraag hoe Jesus as die gekruisigde tot in ewigheid kan leef en regeer? Barth (1953) antwoord:

Seine Geschichte wurde nicht Historie, d. h. sie war wohl seine Geschichte zu seiner Zeit, um gerade als solche ewige Geschichte zu werden: die Geschichte Gottes mit den Menschen aller Zeiten und also auch heute und hier geschehend, wie sie damals geschah. Er ist der lebendige Heiland. (bl. 346)

Jesus is na sy opstanding nie meer vir ons verlede nie maar hede - Hy is hier teenwoordig.

God maak opnuut geskiedenis met die sondige, gevalle en verlore wêreld deur die kruis en die opstanding van Jesus. Die kruis en opstanding staan in samehang met mekaar maar gebeur na mekaar as 'n onomkeerbare verhouding (Barth 1953:341). Deur die kruis en opstanding van Jesus as werklike gebeure word die menslike situasie vir goed grondig verander. Deur die opstanding word Jesus Heer vir alle tye (Barth 1953:348). Daar bestaan 'n dubbele verband tussen die kruis en die opstanding van Jesus. Deur sy eerste koms, ervaar ons Jesus, die opgestane Here, toe en nou, gister en vandag as die lewende, as die gestuurde en die teenwoordige. Ons beleef Jesus ook as die komende, dié een wat weer kom aan die einde van die tyd om die geskiedenis tot voleinding te bring (Barth 1953:367). Jesus is as lewende in sy kerk teenwoordig (Barth 1953:353). Daarom is die hede vir die kerk tyd van afwagting, tyd van vreugde. Met hoop wat op die eindtyd gerig is, lewe die kerk in afwagting op Jesus wat kom (Barth 1953:362).

Met die opstanding van Jesus bevry God die mense van hulle verlede. Opstanding is God se nuwe toewending tot mense om hulle met nuwe lewe te beklee. God bevry mense vir die toekoms (Barth 1953:342). Barth wys daarop dat die regsterm 'A $\pi$ $\lambda$ vं $\rho \omega \sigma 1 \varsigma$, wat dikwels ook gebruik word om die vrykoping van 'n slaaf aan te dui, in die Nuwe Testament gebruik word om die mens se bevryding van sonde, veroordeling en hel aan te dui. Die vrygekoopte mense kry volgens die heersende reg 'n nuwe status. Hulle behoort nie langer aan 'n verslawende mag nie, maar is vry om in die koninkryk van God in te gaan (Barth 1975:121). God se doel met die opwekking van Jesus is om die wêreld met Hom te versoen en om die mense na Hom toe te laat omkeer (Barth 1953:378).

Op die vraag in welke mate die opstanding 'n historiese gebeurtenis is, antwoord Barth (1953:364) dat dit op soortgelyke wyse gebeur het as Jesus se kruisiging en dood, binne menslike ruimte en tyd, as 'n werklike binnewêreldse gebeurtenis van konkrete gehalte. Barth (1948) skryf:

Es ist zunächst wesentlich, zu sehen und zu verstehen, dass es sich bei dem Osterereignis für das Neue Testament tatsächlich um die Ostergeschichte und die Osterzeit handel. Hier genau so um Geschichte und Zeit wie bei den Worten und Taten, hier genau so wie beim Tode Jesu! (bl. 530)

Weber (1967:215) benadruk met reg die genuanseerdheid van Barth se standpunt:
Freilich gibt Barth zu, dass die 'Art', wie die Auferstehung 'als Geschichte $\mathrm{zu}$ verstehen ist', eine andere ist als die der Kreuzigung - es handelt sich hier um einen 'Geschichtsbereich anderer, eigener Art'. (bl. 215)

Die opstanding as werklike gebeure is die inhoud van die apostoliese verkondiging, die inhoud van die gemeente se lewende geloof, asook die bron van die kerk se hoop (Barth 1953:368-369). Hy benadruk egter dat die opstanding nie ongekwalifiseerd aan historiese maatstawwe gemeet kan word nie, 'Als "Historie" kann allenfalls der Tod, als "Historie" kann aber die Auferstehung Jesu Christi nicht erfasst werden' (Barth 1953:370). Weber (1967) verduidelik Barth se standpunt soos volg:

Als 'Historie' - im Sinne der von jedem Betrachter feststellbaren Einsehbarkeit eines in die sonst gegebenen allgemeinen Zusammenhänge sich einpassenden, mit unseren sonstigen Erkenntnissen in Analogie tretenden vergangenheitlichen Vorganges - 'kann allenfalls der Tod', 'kann aber die Auferstehung ... nicht erfasst werden'. (bl. 215)

Dit beteken egter nie dat die opstanding nie werklik plaasgevind het nie, of dat dit bloot ' $n$ produk van die geloof is nie. Die gebeure op Paassondag is die grondslag van die dissipels se geloof op 'n wyse dat die geloof deur die opstanding tot stand kom (Barth 1953:374). Barth (1953:376) maak die fyn waarneming dat die volgelinge van Jesus (volgens die Nuwe Testamentiese berigte) Hom nie in die geloof as opgestane Here ontmoet nie, maar in konflik met hulle ongeloof.

Kruisteologie, geïsoleer van die opstandingsboodskap, is niks anders as mitologie nie (Barth 1953:381). Ons ken nie 'n gekruisigde Jesus as sodanig, in isolasie van 'n opgestane Christus nie. Die gekruisigde Jesus en die opgestane Christus is dieselfde persoon. As eenmalige gebeure staan die kruisiging en opstandeling egter in 'n onomkeerbare verhouding tot mekaar - die opstanding volg op die kruisiging. Barth (1953:379) verduidelik die weg van Jesus van die kruis na die opstanding - as 'n soort 'eenrigtingstraat'. Jesus se dood aan die kruis om mense met God te versoen, is nie die einde van Jesus se weg nie, maar dit is 'n nuwe begin. Barth (1953) formuleer sy standpunt soos volg:

Die Auferweckung Jesu Christi von den Toten war exklusive Gottestat, reine Gottesoffenbarung, freie göttliche Gnadentat. Eben von ihr als solcher redet der Satz: 'Jesus lebt' - von ihr als solcher also auch seine Folge und Fortsetzung: 'Mit Ihm auch ich'. (bl. 394)

Barth (1967:88-90) plaas groot klem op die betekenis van die opstanding vir ons. Na aanleiding van Romeine 4:24 stel hy eerstens dat Christus vir ons geregtigheid verwerf met Sy opstanding. Ons het geen aanspraak op geregtigheid voor God nie en ons besit ook nie geregtigheid voor God nie, maar Christus verwerf vir ons geregtigheid. Barth (1967:89) formuleer die saak bondig: 'Die Auferstehung ist's, die uns in den mit Gottes Willen übereinstimmenden Stand versetzt.' Tweedens meen hy met verwysing na 1 Korintiërs 15:20-23 dat die opstanding van Jesus vir ons 'n betroubare waarborg is dat ons ook in heerlike onsterflikheid sal opstaan. Die lewe is nie tevergeefs nie en verval nie in absolute niks nie. 
Ons word geroep om op te staan. Net soos ons geregtigheid, besit ons egter ook nie ons opstanding nie. Beide word deur Christus vir ons verwerf met sy opstanding. Alle menslike aansprake op onsterflikheid is wensdenkery sonder die waarborg van Christus se opstanding. Derdens redeneer Barth aan die hand van Romeine 6:4 dat wanneer ons in waarheid aan die opstanding van Jesus deelneem, dan staan ons dadelik ook self op tot nuwe lewe om God te dien en om volgens sy wil heilig te lewe. Nou reeds maak opstanding nuwe lewe moontlik. Ons kan nou met vreugde in die diens van God lewe omdat Christus opgestaan het en ons tot nuwe lewe roep.

Met die opstanding maak Jesus Homself bekend as oorwinnaar oor sonde en dood. Met sy opstanding het Hy die dood verslaan, die duiwel oorwin en al sy mag die nek ingeslaan. Barth wys daarop dat die taal wat hy in hierdie verband besig, nie oordrewe beeldspraak is wat voortspruit uit godsdienstige entoesiasme nie, maar dat dit 'n werklikheid beskryf. Hy gebruik die voorbeeld van 'n skaakspel om Christus se oorwinning oor die dood, sonde en Bose treffend toe te lig. In 'n skaakspel kan dit gebeur dat dit onafwendbaar is dat die een koning in die 'skaakmat' posisie gaan kom. Daar is wel nog 'n paar skuiwe nodig, maar die bepaalde uitkoms van die spel is onafwendbaar: 'Nach der Auferstehung Christi gibt es keinen herrschenden Tod, keine regierende Sünde mehr. Sicherlich existieren Tod, Sünde und Teufel weiterhin, aber als besiegte Dinge' (Barth 1967:91).

Met die betekenis van Christus se opstanding vir ons as vertrekpunt, besin Barth verder oor die werklikheid van die opstanding. Die vrug van die opstanding is nie wense, drome, of innerlike gevoelens nie, maar werklikheid. Barth (1967) verduidelik:

Mit anderen Worten, wer die Wirklichkeit der Gerechtigkeit, der Auferstehung und des neuen Lebens, die ihm durch die Auferstehung Christi erworben sind, nicht begreift, der braucht auch die Wirklichkeit der Auferstehung Christi nicht. (bl. 90)

Barth (1967:91-92) meen dat die opstanding ons konfronteer met die keuse van alles of niks (entweder - oder). Die opstanding van Jesus is die grootste bedrogspul waarmee die arme mensdom nog aan die neus gelei is, of dit is die daad van God wat geloof stig, oorwinning oor die sonde, dood en Bose aankondig en nuwe lewe bewerk. Die evangelieboodskap is ' $n$ uitnodiging om te glo. Daar breek 'n nuwe tyd in die wêreldgeskiedenis aan met die opstandig van Jesus. Die nuwe tyd is die tyd van die kerk. Dit is die tyd waarin God met groot geduld die evangelie aan mense laat verkondig, aan hulle ruimte bied om daaroor na te dink, dit te verstaan en dit te glo (Barth 1967:92). Jesus se oorwinning kry beslag in ons geloof. Die geloof groei uit die oorwinning wat behaal is. Die geloof kom tot stand deur die oorwinning van Christus. Die boodskap van oorwinning is nie eers die gevolg van die geloof nie. Geloof is daarom nie 'n menslike gedagte oor God nie, maar die gevolg van God se liefdesdade aan die mens (Barth 1967:93).

Barth (1967:93) wys daarop dat Jesus nie uit die dood uit opgestaan het (of dan deur God uit die dood opgewek is), soos wat mens uit die slaap wakker word (of wakker gemaak word) en opstaan om later weer te gaan slaap nie. Christus het opgestaan om te lewe - sonder om weer te sterwe. As opgestane Here, ontmoet die gelowiges Hom dan ook as die Lewende.

Ons mense ken nie 'n ander lewe en kan ons ook nie 'n ander lewe voorstel as 'n liggaamlike lewe nie, daarom is dit vanselfsprekend dat Jesus se opstanding dan ook 'n liggaamlike opstanding is (Barth 1967:94). Omdat 'n liggaamlose lewe onmenslik is, verkondig die Nuwe Testament die liggaamlike opstanding van Jesus. Dit is die geloof waartoe die Nuwe Testament ons oproep. Ons kan hierdie boodskap aanneem, of dit afwys; ons kan dit egter nie verander nie. Barth (1967:95) se raad aan ons is eenvoudig: 'Und wenn es uns schwerfällt zu glauben, dann wollen wir lieber, ehe wir die Botschaft verändern, Gott darum bitten, er wolle uns durch seinen Heiligen Geist den Glauben schenken.' In hierdie verband is 'n opmerking wat Eberhard Jüngel (1982:18) kort na Barth se dood met verwysing na sy teologie gemaak het heel van pas: 'Eine ordentliche Theologie macht keine Kompromisse.'

Barth ontken nie die feit dat die Nuwe Testamentiese getuienis oor die opstanding van Jesus soms in teenspraak met mekaar is nie. Nugter doen hy aan die hand dat mens nie moet probeer om die onderskeie berigte oor die opstanding met mekaar te probeer harmoniseer om 'n eenduidige opstandingsberig te probeer konstrueer nie. Ons moet onthou dat ons hier met ' $n$ daad van Goddelike genade te make het wat die menslike verstaan daarvan te bowe gaan en dat die onderskeie berigte oor die opstanding blote brokstukke van menslike getuienis is. God alleen kan die waarheid van die opstanding bewys (Barth 1967:95).

\section{Rudolf Bultmann (1884-1976)}

Enige beskrywing of beoordeling van die teologiese werk van Bultmann wat oor die opstanding van Jesus handel, behoort die spesifieke tema wat op die tafel kom binne die breër raamwerk van Bultmann se unieke benadering tot teologie aan die orde te stel. Elke poging om Bultmann se opvatting oor die opstanding van Jesus te isoleer van die geheel van sy teologie, sal daartoe lei dat 'n skewe beeld van sy standpunt aangebied word. Walter Schmithals (1967) beskryf samevattend die fokuspunt van Bultmann se teologie treffend met die volgende woorde:

Der Weg aus der Uneigentlichkeit in die Eigentlichkeit, biblisch gesprochen: aus der Sünde zum Glauben, aus dem Tode zum Leben, aus der Verlorenheid zum Heil ist - soweit haben wir Bultmann verstanden - ein Weg, den nur Gott dem Menschen wieder eröffnen kann. Der gefallene Mensch vermag sein Leben, sein Heil nur als ein Geschenk Gottes, nur als Gnade anzusehen. Mit anderen Worten: Glaube ist nur als 'Glaube an ...' möglich; er setzt ein Heilsgeschehen, ein Handeln Gottes voraus, das Grund und Gegenstand des Glaubens ist. (bl. 129)

Hierdie beskrywing van Schmithals kan as vertrekpunt dien, vir die ontwerp van 'n sistematiese konteks waarbinne die denke van Bultmann oor die opwekking van Jesus aangebied 
kan word. Bultmann benadruk uitdruklik dat alleen sinvol oor God se handeling gepraat kan word, as ons aanvaar dat gelowige uitsprake oor God se handeling nie bloot as simboliese taal vir ' $n$ ander saak aangebied word nie, maar dat dit 'ein Handeln in vollem, realen, "objektiven" Sinne' beskryf (Bultmann 1952:196). Bultmann (1961) skryf in hierdie verband:

Freilich unterscheidet es sich von Heilsereignissen, von denen der Mythos der Mysterienreligionen und die Gnosis berichten, dadurch, dass es sich um eine geschichtliche Person, um Jesus, handelt, und dass dessen Tod am Kreuz, der erst wenige Jahre zurückliegt, im Mittelpunkt des Heilsgeschehens steht. (bl. 294)

God se handeling, met ander woorde die heilsgebeure, is nie ' $n$ innerlike verandering aan die gemoed van die mens nie, maar dade wat buite die mense voltrek word in die geskiedenis van die wêreld (Bultmann 1976:161). Die beskuldigings wat dikwels teen Bultmann ingebring word dat hy die werklikheid van die opwekking van Jesus sou ontken, kan reeds hier as ongegrond en waarskynlik as oningelig weerlê word. Bultmann het nooit die werklikheid van God, sy handelinge, of die opwekking van Jesus in twyfel getrek nie. Net soos die gelowige mens, veronderstel Bultmann as Christelike teoloog ook die heilsgebeure as handeling van God. Waarteen hy wel deurlopend beswaar gemaak het, is die wyse waarop mense dikwels oor hierdie sake praat. Bultmann het dit daarteen dat mense al te dikwels meen ons kan objektiverend oor die werklikheid van God praat. Bultmann (1952) skets die problematiek waaroor dit gaan duidelik in die volgende sitaat:

Wenn aber das Handeln Gottes nicht als ein Weltphänomen verstanden werden darf, das abgesehen von der existensiellen Betroffenheit von ihm wahrgenommen werden kann, so kann von ihm nur geredet werden, indem zugleich von mir, dem Betroffenen, geredet wird. Von Gottes Handeln reden, heisst zugleich von meiner Existenz reden. Da menschliches Leben ein Leben in Raum und Zeit is, kann die Begegnung Gottes für den Menschen nur ein Ereignis jeweils hier und jetzt sein. Dieses Ereignis, von Gott hier und jetzt angeredet, gefragt, gerichtet, gesegnet $\mathrm{zu}$ werden, ist gemeint in der Rede vom Handeln Gottes. (bl. 196)

Dit is natuurlik van belang om vas te stel wat Bultmann wel as heilsgebeure, as die handeling van God verstaan wat ons aanspreek, uitvra, oordeel en seën. Hy meen die Nuwe Testament verkondig Jesus as die beslissende heilsdaad van God. Die Nuwe Testament verkondig Jesus nie in die eerste plek as voortreflike leeraar wat voortdurend deur ons vereer moet word omdat Hy belangrike sake vir ons kom leer het nie, maar as persoon deur wie God Sy beslissende heilsdaad voltrek het (Bultmann 1952:25). Aan die hand van Paulus se teologie redeneer Bultmann dat God se handeling in Christus heilshandeling is. Paulus verstaan God as regter (2 Kor 5:10). God se genade en liefde is nie bloot 'n genadige of liefdevolle gesindheid van God nie, maar die genadige en liefdevolle optrede van God, die Regter van elke mens. As genadige Regter tree God absoluut vry op, omdat Hy deur geen menslike aanspraak verplig word tot genadige optrede nie. God se genade is in die radikale sin van die woord genade (Bultmann 1961:285-292). Die boodskap van God aan ons is dat Hy 'deur Christus die wêreld met Homself versoen het en die mense hulle oortredinge nie toereken nie' (2 Kor 5:19).

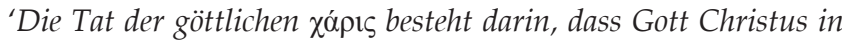
den Tod am Kreuz gegeben hat' (Bultmann 1961:292). Die fokus van Paulus se verkondiging is op Christus, die Gekruisigde gerig (1 Kor 1:23) en die evangeliese boodskap is sonder uitsondering die boodskap van die gekruisigde Christus (1 Kor 1:18). Dit beteken nou nie dat die heilsgebeure of die Christelike evangelieverkondiging tot die kruis beperk word nie. Die verkondiging van Jesus se opwekking is ook deel van die Christelike boodskap: 'Christus Jesus het gesterf, maar meer as dit: Hy is uit die dood opgewek, Hy sit aan die regterhand van God, Hy pleit vir ons' (Rom 8:34). Net soos wat Paulus na die kruis kan verwys, sonder om die opstanding te noem, kan hy ook na die opstanding verwys, sonder om die kruis te noem (Rom 10:9). Jesus se verkondiging, dade, persoonlikheid of lewe kom by Paulus nie in die visier as heilsgebeure nie, maar wel sy dood en opstanding. Die historiese Jesus word nie deur Paulus verkondig nie, maar wel die verhoogde Here (Bultmann 1961:293).

Bultmann (1978:377) toon aan die hand van die Evangelie volgens Johannes dieselfde saak aan: 'Als historisches Ereignis wird Jesu Leben alsbald ein Stück Vergangenheit sein; aber so betrachtet offenbart es auch nicht seine dó $\xi \alpha$. ' Hy gaan voort: 'Wer bei dem durch historische Erinnerung rekonstruierten "historischen Jesu" verweilen will, muss bald inne werden, dass er ohne ihn ist' (Bultmann 1978:377). Paulus wil Jesus nie volgens menslike maatstawwe beoordeel nie, maar sy dood en opstanding as heilshandeling van God verkondig (Bultmann 1961:294).

Net soos wat Bultmann nie die werklikheid van God of die handeling van God betwyfel nie, betwyfel hy ook nie die werklikheid van die opwekking van Jesus deur God nie. Waarteen Bultmann dit wel het, is die mening dat die opstanding as historiese gebeurtenis as legitimasie van ons opstandingsgeloof kan dien. Bultmann glo met ander woorde in die opstanding van Jesus, maar hy ontken dat die historiese feit van die opstanding die grondslag kan vorm vir ons geloof in die opwekking van Jesus as heilsdaad van God. In kort kom dit daarop neer dat geen historiese inligting die plek kan inneem van gelowiges se onvoorwaardelike vertroue op God nie.

Sowel die evangeliese berigte oor Jesus se opwekking as die Nuwe Testamentiese belydenisse oor sy opwekking is nie historiese verslae wat as bewyse van die opstanding van Jesus kan dien nie. Volgens Bultmann (1960:47) is die enigste bewysbare historiese gebeure wat verband hou met Jesus se opstanding die eerste dissipels se opstandingsgeloof. Ons kan egter nie ons geloof op ander mense se geloof bou nie en die dissipels se geloof kan ook nie as basis dien waarvan ons die opstanding van Jesus as historiese feit kan aflei nie. Die feit dat ons nie Jesus se opstanding as 'n historiese feit (aan 'n ongelowige wêreld) kan bewys nie, omdat ons eenvoudig nie oor die nodige historiese materiaal beskik wat die historisiteit van die opstanding vir ons kan bevestig nie, skep egter nie vir Bultmann as gelowige 'n 
verleentheid waaruit hy moet probeer ontsnap nie. Trouens, die laaste ding wat Bultmann probeer doen, is om Jesus se opstanding as bloot ' $n$ historiese gebeurtenis aan die orde te stel. Jesus se opwekking is ' $n$ heilsdaad van God en moet as sodanig vertolk word. Indien ons Jesus se opstandeling wel as ' $n$ historiese gebeurtenis takseer, wat ons objektief met historiese navorsing probeer verifieer, sou sy opstanding nie alleen ongeloofwaardig wees as 'n verhaal oor die herlewing van 'n lyk nie, maar dit sou ook nie uniek wees nie, omdat baie soortgelyke verhale oor die herlewing van gestorwe mense in die godsdiensgeskiedenis van die wêreld bestaan. Op hierdie punt is dit nie alleen Bultmann se verkrampte vyande wat hom as ongelowige probeer brandmerk wat 'n verbasende gebrek aan begrip vir sy teologie ten toon stel nie, maar ook sy postmoderne kritici wat aanvoer dat Bultmann 'verder moes gaan' deur die kerugma van Jesus se opwekking as net nog ' $n$ antieke en naïewe verhaal te lees soos baie ander soortgelyke stories wat oor die herlewing van ' $n$ held handel. Bultmann stel nie in die minste daarin belang om deur historiese navorsing die opstanding van Jesus te bewys, of om dit deur 'n proses van vergelykende godsdiens-historiese analise as 'n godsdienstige fenomeen te beskryf, of om objektiverend, as toeskouer, dit te beskryf nie. Die teologie moet Jesus se opstanding as heilsdaad van God interpreteer - 'n heilsdaad wat elke mens se lewe ten nouste raak.

Bultmann se vernaamste beswaar teen die objektivering van die opstanding van Jesus is dat dit nie van die vernietiging van die doodsmag as sodanig getuig nie. Selfs al sou dit moontlik wees om die opstanding van Jesus as historiese feit te verifieer, is dit nie moontlik om deur waarneming, in die lig van die mens se sonde en God se genade, die opstanding van Jesus as heilsdaad van God te bewys nie. Die Christelike geloof verstaan Jesus se opwekking in die radikale sin van die woord as heilsdaad van God, as 'n ervaring met God wat die mens alleen eksistensieel kan beleef. Vanuit hierdie perspektief stel gelowiges nie belang in historiese vrae oor die opstanding van Jesus nie.

Bultmann (1960:44) wys daarop dat Jesus se kruis en opstanding in die Nuwe Testament deurgaans as 'n eenheid ter sprake kom. Schmithals (1967:142) beskryf Bultmann se opvatting met 'n paradoksale formulering: 'es ist der Auferstandene, der am Kreuz stirbt. Unmöglich kann dann die Auferstehung das Kreuz als Heilsereignis legitimieren.' Die kruis (as heilsgebeure) is net soos die opstanding (as heilsgebeure) 'n saak van geloof. Mens kan nie een geloof (die geloof in die heilsbetekenis van die opstanding) gebruik om 'n ander geloof (die geloof in die heilsbetekenis van die kruis) te legitimeer nie. Dat God met die kruis en die opstanding van Jesus gehandel het, word deur een en dieselfde evangelie aan ons verkondig, daarom kan ons nie die twee sake van mekaar skei met die doel dat ons geloof in die een saak die grondslag sal vorm vir ons geloof in die ander een nie. Ons glo immers nie eers in Jesus en dan later ook in sy kruis en opstanding nie. Net so glo ons ook nie eers in die heilsbetekenis van Jesus se opstanding en dan later in die heilsbetekenis van sy kruis nie.
Bultmann meen die basiese dwaling van sommige teoloë is om te probeer om God se handeling te objektiveer. Net so min as wat mens God as 'n objektiewe gegewendheid kan beskou of kan beoordeel, net so min kan mens God se handeling as objektiewe gebeure beoordeel. 'God' as 'n objektiewe werklikheid is nie werklik meer God nie, maar 'n afgod, 'n skepping van die mens. Geen mens kan oor die handeling van God of die openbaring van God beskik nie:

Das Handeln Gottes bezieht sich nicht auf ein Geshehen, das ich bemerken kann, ohne selbst in das Handeln heineingezogen zu sein als in Gottes Handeln, ohne dass ich selbst daran teilhabe als der, an dem gehandelt wird. Mit anderen Worten: Die Rede vom handelnden Gott schliesst die Geschehnisse der eigenen Existenz ein. (Bultmann 1975a:177)

Bultmann (1961) meen:

die Entscheidungsfrage, ob der Mensch sein altes Selbstverständnis fahren lassen und sich ganz aus der Gnade Gottes verstehen will, und die Frage, ob er Christus als den Sohn Gottes und Herrn anerkennen will, ein und dieselbe Frage sind. (bl. 300)

Hy verstaan dan ook hierdie beslissende vraag aan elke mens as die 'echte Entscheidungsfrage' (Bultmann 1961:294, 1967:464) waarvoor elke mens gestel word. Die benadering wat Bultmann hier uiteensit, gaan daarvan uit dat geloof baie meer behels as net om seker historiese feite as waar te aanvaar. Geloof dien die eer van God en Christus en die heil van die mens. In sy 1954-1955 'Gifford Lectures' oor 'historie en eskatologie' en die 'teenwoordigheid van ewigheid' sê Bultman ([1954-1955] [1962] 1975b) onder andere:

For in the decision of faith I do not decide on a responsible action, but on a new understanding of myself as free from myself by the grace of God and as endowed with my new self, and this is at the same time the decision to accept a new life grounded in the grace of God. (bl. 152)

Die werklikheid dat God ons deur die kruis en opstanding bevry van sonde, is onbegryplik, net soos wat God se genade vir ons onbegryplik is. Die Bybelse berigte wat van die heilsdade van God vertel, is self nie die waarborg vir die waarheid en die werklikheid van die mens se bevryding deur God van sonde en dood nie. Die kruis van Jesus as 'n gebeurtenis wat ons van ons heil oortuig, kan nie objektief verstaan word en eers nadat dit verstaan word, ontvang ons heil van God nie. Nee, dieselfde oomblik as wat ons die heil aanneem wat God aanbied, ervaar ons God se genade deur die kruis. Die kruis is nie net simbool van heil nie, dit is die wyse waarop God ons heil bewerk. Dieselfde geld ook vir die opstanding. Ons moet saam met Christus gekruisig word, om saam met Hom op te staan. Geloof in die kruisiging en opstanding van Jesus kan nie beteken dat mens objektief, klinies, of afsydig die historiese werklikheid van die kruis en opstanding as waar aanvaar nie (Bultmann 1969:64, 1977:9, 148). Geloof in die kruis en die opstanding beteken om die beslissing te maak, dat kruis en opstanding die bepalende krag van jou hele lewe word. Bultmann (1961) formuleer die saak treffend:

solche Erkenntnis vollzieht sich nur als Anerkenntnis. Das ist

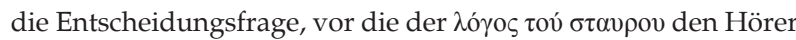
stellt, ob er anerkennen will, dass Gott einen Gekreuzigten zum 
Herrn gemacht hat; ob er damit die Forderung anerkennen will, in der Preisgabe seines bisherigen Selbstverständnisses das Kreuz zu übernehmen, es zur bestimmenden Macht seines Leben werden zu lassen, sich mit Christus kreuzigen zu lassen. (bl. 303)

Dit gaan in die geloof daaroor dat die Gekruisigde as Here verkondig word en dat die opgestane Jesus Here is (Bultmann 1968:178). Slegs waar die gekruisigde en opgestande Jesus as Here bely word, is die kruis en opstanding as heilsgebeure herkenbaar (Bultmann 1952:199).

Geloof is 'n waagstuk! Geloof is 'n waagstuk nie alleen omdat dit nie op bewysbare objektiewe feite gebou word nie, maar veral ook omdat geen egte vertroue en geen opregte liefde sonder risiko is nie. Geloof is onvoorwaardelike vertroue op die dade en die beloftes van God. Net so is dit opregte liefde vir God. God se trou en liefde kan nie bewys word asof dit 'n objektiewe feit is nie en waar mense probeer om God se dade aan objektiewe kontrole te onderwerp, gee hulle noodwendig hulle vertroue in God prys. God word dan ook in die proses tot ' $n$ objek gemaak wat voorhande is en so word Sy eer aangetas (Bultmann 1952:199). Bultmann (1961) stel onomwonde:

dass die Person und das Schicksal Jesu nicht im Zusammenhang innerweltlichen Geschehens ihren Ursprung und ihre Bedeutung haben, sondern dass Gott in ihnen gehandelt hat..., und zwar zum Heil der Menschen, für die er Christus dahingegeben hat. (bl. 304)

Indien die opstanding verkondig word as die opstanding van die Gekruisigde het dit nie enige mirakelagtige kwaliteite nie. Die opstanding word dan nie verstaan as die terugkeer van ' $n$ afgestorwene na hierdie wêreld nie. Dit gaan by die opwekking van Jesus vir Bultmann uit en uit oor die verhoging van die Gekruisigde tot heerskappy, sodat geloof in die opwekking van Jesus niks anders is as geloof in die kruis as heilsgebeurtenis nie.

Indien ons aanvaar dat die verkondiging van die heilsgebeure nie net die bekendmaking van inligting is nie, maar'n oproep tot geloof - 'n oproep tot die mens om hom- of haarself prys te gee en om te keer na God toe, dan beteken dit dat die heilsgebeure nêrens anders as juis in die verkondigde woord teenwoordig is nie (Bultmann 1977:148). Bultmann (1980:208) skryf: 'Jesus Christus begegnet dem Menschen nirgends anders als im Kerygma ... .' Waar die evangelie ons aanspreek, oproep, of God se beloftes aan ons verkondig, juis daar ontvang ons heil van God. Dit beteken dat die verkondiging nie net met ons oor die heil praat wat God skenk nie, maar dat die verkondiging self ook deel van die heilsgebeure is. Bultmann (1961) verduidelik:

Es heisst, dass sich das Heilsgeschehen in der Verkündigung des Wortes weiter vollzieht. Eben darin ist das Heilsgeschehen eschatologisches Geshehen, dass es nicht $\mathrm{zu}$ einem Faktum der Vergangenheit wird, sondern ständig in der Gegenwart neu geschieht, - präsent nicht in der Nachwirkung eines bedeutsamen weltgeschichtlichen Faktums, sondern in der nicht in die Entwicklung der Geistesgeschichte eingehenden Verkündigung. (bl. 302)
Bultmann (1980) verduidelik sy standpunt oor die betekenis van die persoon Jesus (die Jesus wat in die geskiedenis geleef het) vir die verkondiging van die evangelie soos volg:

Das Kerygma verkündigt nicht allgemeine Wahrheiten, eine zeitlose Idee, sei es eine Gottes - oder eine Erlöser-Idee, sondern ein geschichtliches Faktum. Aber das tut es nicht in dem Sinne, dass es sich selbst überflüssig macht, ...

Man darf also nicht hinter das Kerygma zurückgehen, es als 'Quelle' benutzend, um einen 'historischen Jesus' mit seinem 'Messiasbewusstsein', seiner 'Innerlichkeit' oder seinem 'Heroismus' zu rekonstruieren ... Nicht der historische Jesus, sondern Jesus Christus, der Gepredigte, ist der Herr.

Deshalb kann Paulus ebenso wie Tod und Auferstehung Jesu, so auch die Predigt des Evangeliums als die Heilstat Gottes, ... als den Anbruch der Heilszeit bezeichnen (2. Kor. 5, 17-20). Das eschatologische Jetzt von Tod und Auferstehung Jesu ist also nicht ein vergangener Moment in der verfliessenden Zeitreihe, sondern als eschatologisches Jetzt ist es dadurch ausgezeichnet, dass es überall da Gegenwart ist, wo die Predigt erklingt ... Die Predigt ist das Heilsgeschehen, weil sie keine blosse historische Mitteilung ist, sondern, so wie sie dem Paulus selbst begegnete, die entscheidende Frage an den Menschen. (bl. 208-209)

Die opstanding kan nie as objektiewe feit (bv. aan die hand van 1 Kor 15:3-8) bewys word, waaraan die gelowige dan kan glo nie. Alleen in geloof kan die waarheid van die opstanding aanvaar word. Die verkondiging van Jesus as die opgestane Here is alleen geloofwaardig omdat die opgestane Here self in die verkondigde Woord teenwoordig is. Die geloof dat Jesus opgewek is en die geloof dat Jesus self in die verkondigde Woord aan die woord kom, of dat God self deur die verkondigde Woord met ons praat, is identies (Bultmann 1961:305). Soos die opwekking van Jesus, is die verkondiging van die opgestane Christus as Here, eskatologiese gebeure. Deur die evangelie word die hoorder persoonlik aangespreek. Hoor die mens wat in die strikke van die dood vasgevang is, die woord van lewe, glo daardie persoon in Jesus, die opgewekte Here (Bultmann 1961:306).

\section{Kritiese vrae van Barth aan Bultmann}

Barth (1948:531-537) doen moeite om in Die Kirchliche Dogmatik, Band III/2 'n uitvoerige uiteensetting van sy interpretasie van Bultmann se teologie en sy kritiek daarop aan te bied. Die kern van Barth (1948) se interpretasie word moontlik in die volgende woorde saamgevat:

Das wirkliche Osterereignis im Zusammenhang jenes eschatologischen Geschehen ist die durch kein zeitliches Geschehen, sondern allein durch die überhistorisch-überzeitliche Tat Gottes begründete Entstehung des Osterglaubens der ersten Jünger. Dem Osterglauben der späteren Kirche und unserem Osterglauben bedeutet sie jedenfalls eine Tat Gottes: 'die Tat Gottes, in der sich das Heilsgeschehen des Kreuzes vollendet'. (bl. 533)

Uit hierdie interpretasie van Bultmann se denke maak Barth dan die volgende afleiding: 'Die "Selbstkundgabe" des "Auferstandenen"' spielt sich in ihnen selbst und nur in ihnen ab. Es geschah nichts zwischen ihm und ihnen' (Barth 1948:533). Barth (1948) se kritiek op Bultmann is vanselfsprekend in die lig van sy interpretasie van Bultmann: 
Ihr Glaube hatte keinen von seiner eigenen Wirklichkeit verschiedenen Gegenstand, keinen Grund, durch den er als Glaube allererst begründet gewesen wäre. Er stand souverän auf sich selber. Die 'Tat Gottes' war identisch damit, dass sie glaubten ... Jesus selber war eben nicht auferstanden. (bl. 534)

Die interpretasie wat Barth hier van Bultmann aangebied het en die kritiek op Bultmann wat hy op hierdie interpretasie gegrond het, sou baie gou die prisma word waardeur baie mense na Bultmann se teologie kyk. Sommige eietydse aanvalle op die teologie van Bultmann wil die indruk skep dat Barth hier finaal met Bultmann se teologie klaargespeel het en Barth word, wat hierdie saak betref, dan ook klakkeloos nagepraat.

\section{Bultmann se reaksie op Barth se kritiek}

Bultmann (1968:233-235) het reeds so vroeg as 1950 aangedui dat die essensie van Barth se kritiek op sy teologie nie alleen op 'n foutiewe interpretasie (völliges Missverständnis) van sy teologie berus nie, maar dat dit ook meer vrae skep as wat dit oplos. Uit die aard van die saak het Bultmann nie genoeë daarmee geneem dat Barth sy teologie reduseer tot 'Sätze über das innere Leben des Menschen' nie. Hy wys verder daarop dat Barth geredelik toegegee het dat Jesus se opstanding nie ' $n$ historiese feit is wat deur die historiese wetenskap geverifieer kan word nie. Dit beteken, volgens Barth, egter nie dat die opstanding nie gebeur het nie en daarom nie geskiedenis is nie. Barth (1948) skryf:

Kann sich nicht auch solche Geschichte wirklich ereignet haben, und kann es nicht eine legitime Anerkennung auch solcher Geshichte geben, die 'historisches Faktum' zu nennen man schon aus Gründen des guten Geschmacks unterlassen wird, die der 'Historiker' im modernen Sinn des Begriffs gut und gerne 'Sage' oder 'Legende' nennen mag, weil sie sich den Mitteln und Methoden samt den stillschweigenden Voraussetzungen dieses Historikers in der Tat entzieht? (bl. 535)

Bultmann wil van Barth weet wat hy onder die begrippe 'Geschehen' en 'Geschichte' verstaan? Watter gebeurtenisse het Barth in die oog wanneer hy elders (Barth 1948:535-536) beweer dat dit met groter sekerheid gesê kan word dat hierdie gebeure wel gebeur het as die gebeure wat deur historici bevestig kan word as dat dit wel gebeur het? Bultmann meen Barth bedien hom van begrippe waarvan die betekenis onduidelik en verwarrend is en wat hy boonop inspan as vertrekpunt om die Bybel te interpreteer. Bultmann wil ook van Barth weet hoe dit moontlik is dat gebeure wat nie deur historiese navorsing bevestig kan word nie vir die gelowige toeganklik word? Behels geloof wat op sodanige 'kennis' gebou word nie die blinde aanvaarding van bewerings en dus 'n geval van Sacrificium Intellectus nie? Hy toon ook aan dat Barth nou maar eenmaal net nie in voeling wil kom met sy eksistensiale interpretasie van mites nie.

Bultmann is al daarvan verwyt dat hy die opstanding as objektiewe werklikheid sou prysgee en dit bloot as 'n subjektiewe psigologiese belewenis sou beskryf. Hy antwoord op hierdie verwyt soos volg: 'Aus der Feststellung dass von
Gott reden von mir selbst reden heisst, folgt keineswegs, dass Gott nicht ausserhalb des Glaubenden ist' (Bultmann 1975a:179). Geloof is nie 'n psigologies subjektiewe gebeurtenis nie. In die lig hiervan redeneer hy dat om die Skrif as God se woord te hoor, beteken om ' $\mathrm{n}$ woord te hoor wat my aanspreek as Kerygma, as 'n aankondiging. Ek kan die evangelie daarom nie uit 'n neutrale oogpunt verstaan nie, want my verstaan daarvan is reeds my antwoord op die roepstem daarvan. Mens kan nie objektief vasstel dat die woord van die Skrif God se woord is nie. God se woord in die Skrif is verborge, net soos wat God oral verborge is. Ons kan ook nie God se heilsdade demonstreer nie. God se handeling verleen egter aan ons 'n nuwe verstaan van onsself. Bultmann (1975a) stel met nadruk:

Dieses lebendige Gotteswort ist nicht von Menschengeist und Menschenklugheit erfunden; es ereignet sich in der Geschichte. Sein Ursprung ist ein geschichtliches Ereignis, durch welches das Sprechen dieses Wort, die Predigt, autoritativ und legitim wiedergeben wird. Dieses Ereignis ist Jesus Christus. (bl. 185)

Bultmann (1975a) meen ons het met 'n egte paradoks te make wanneer dit by Jesus kom:

Jesus ist eine menschliche geschichtliche Person aus Nazareth in Galiläa. Sein Werk und sein Schicksal geschehen in der Weltgeschichte und fallen als solche unter die Untersuchung des Historikers, der sie als Teil des fortlaufenden Geschichtsfadens verstehen kann. Dennoch kann solche isolierte geschichtliche Untersuchung dessen nicht innewerden, was Gott in Christus getan hat, nämlich des eschatologischen Ereignisses. (bl. 185)

\section{Weer eens Barth}

Barth is dit met Bultmann volkome eens dat geloof in die opstanding van Jesus nie bloot die onderskrywing van proposisionele stellings oor Jesus se opstanding kan behels wat as algemene en objektiewe waarhede aan ons voorgehou word nie. Hy distansieer hom van die positivisties-ortodokse opvatting dat geloof die 'Fürwahrhalten' van 'bezeugenden oder verkündigenden Sätzen' is (Barth 1953:850). Die hermeneutiese vraag na die teenwoordigstelling (Vergegenwärtigung of repraesentatio) van Jesus Christus en sy heilswerk is vir beide teoloë van fundamentele belang. Op hierdie punt skei die weë tussen die twee dan ook. Barth is redelik geniepsig in sy kommentaar op Bultmann wat hierdie saak betref. Sy kommentaar kom daarop neer dat Bultmann se teologie niks anders is as 'n eksistensiële transsubstansiasieleer nie. Hy skryf die volgende oor Bultmann se standpunt:

Was in der Erkenntnis des pro me des christlichen Glaubens allendings Ereignis wird, das ist gerade nicht die Heilstat Gottes selbst, nicht der Tod und nicht die Auferstehung Jesu Christi, keine Vergegenwärtigung und kein Nachvollzug seines Gehorsams, seines Opfers und seines Sieges. Was ist die Konzeption Bultmans anderes als die existenzialistische Übersetzung der sakramentalistichen Doktrin der römischen Kirche, der zufolge es auf dem Höhepunkt der Messe, im Vollzug der Wandlung der Elemente zugleich - in metaphysischer Identität mit dem damals und dort Geschehenen - zu einer 'unblutigen Wiederholung' des Opfers Christi auf Golgatha kommt? (Barth 1953:858)

(Barth 1953:858) se standpunt is eenvoudig dat die geskiedenis van Jesus Christus nie met die geloof van die gelowiges 
saamval (koinzidieren) nie. Hy meen ons moet nie ons begrip (erkennendes Ergreifen of comprehendere) van Jesus se dood en opstanding verwar met ons eie geloof nie. Bultmann stel hom wel bloot aan kritiek soos dié van Barth, met uitlatings soos by voorbeeld sy slotopmerkings van die Gifford-lesings van 1955 (gepubliseer onder die titel History and Eschatology):

But now we can say: the meaning in history lies always in the present, and when the present is conceived as the eschatological present by Christian faith the meaning in history is realised ... Always in your present lies the meaning in history, and you cannot see it as a spectator, but only in your responsible decisions. In every moment slumbers the possibility of being the eschatological moment. You must awaken it. (Bultmann [19541955] [1962] 1975b:155)

Het Barth sy kritiek op Bultmann nie te ver gevoer nie? Ons sou ook die wenkbroue kon lig vir die uitspraak waarmee hy sy kommentaar op Bultmann se teologie afsluit in Band IV /1 van Die Kirchliche Dogmatik:

Er wird also, wenn er von dem, was in Glauben geschieht, redet, gerade nicht von einer absoluten Erschütterung, gerade nicht von einer eschatologischen Entscheidung, gerade nicht von der Heilstat Gottes reden. (Barth 1953:858)

\section{Bultmann voor die regterstoel van Barth}

Daar is reeds op gewys dat Barth in sy gesprek met Bultmann 'n bepaalde intellektuele spitsvondigheid aan die dag lê wat in die rigting van geniepsigheid neig. Sy beskrywing van Bultmann se teologie as 'die existenzialistische Übersetzung der sakramentalistischen Doktrin der römischen Kirche' is 'n voorbeeld hiervan. Hy meen ook Bultmann verteenwoordig die welbekende 'reichlich humorlose Marburger Tradition' wat nie vryhede toelaat nie en onder 'der Diktatur der Marburger Kant-Schule' staan (Barth 1948:536). Barth skep amper die indruk dat hy ietwat afgunstig op Bultmann se Marburgse verbintenis is, want elders kom dit ook weer ter sprake (Barth 1994:281). Om hierdie rede is Barth se reaksie soveel meer merkwaardig toe hy in 1947 om advies oor Bultmann se teologie genader is deur die voorsitter van die Raad van die Evangeliese Kerk in Duitsland, Landesbischof D. Theophil Wurm, nadat die Raad 'n klagte moes hanteer oor Bultmann se teologie en sy invloed by Marburg se teologiese fakulteit wat van ene pastor Hans Bruns ontvang is. Ondanks die verskille tussen dié twee, skryf Barth met die grootste respek en agting nie net oor Bultmann se fenomenale filologies-kritiese vaardigheid, wat byna ongeëwenaard is, en sy eksegetiese en dogmatiese vakkundigheid wat so indrukwekkend is nie, maar ook oor die konsekwentheid waarmee hy sy standpunte handhaaf en die eerlikheid waarmee hy teologie bedryf. Barth se advies aan Wurm neem eintlik in 'n groot mate die vorm aan van 'n getuigskrif wat die wedersydse respek en lojaliteit tussen die twee strydrosse uitlig. Barth sukkel egter ook om sy minagting vir die optrede van pastor Bruns weg te steek, nie net wanneer hy die klaer in die Bultmann-saak se algemene vakkundige onkunde blootlê nie, maar ook wanneer hy die moontlike skade oorweeg wat optrede soos dié vir die welsyn van die kerk tot gevolg kan hê. Uit 'n brief van Wurm aan Barth (Barth 1994:286) blyk dit dat 'n 'drohende Gefahr einer neuen theologischen Aufspaltung der evangelischen Kirche' in die tyd wel gedreig het.

In sy advies beskryf Barth (1994) Bultmann se teologie akkuraat as om:

eine Neuorientierung der evangelischen Theologie im Sinne einer in ihrer Exegese und Systematik sichtbar zu machenden klaren Konfrontierung des menschlichen Subjekts mit der ihm begegnenden göttlichen Offenbarung bemüht haben. Man wird beachten müssen, dass es dieser Grundabsicht bis auf diesen Tag getreu geblieben ist. (bl. 276)

Barth is nie bekommerd oor die uitkomste van Bultmann se teologie nie. Hy meen die uitkomste (die Christologiese konklusies) van Bultmann se teologie is die resultaat van konsekwente, logiese denke vanuit bepaalde vertrekpunte. Barth het wel ernstige voorbehoude oor die uitgangspunte van Bultmann se teologie, naamlik dat hy die filosofiese ontologie (meer spesifiek die eksistensialistiese antropologie) van sy tyd as die adekwate kanon vir die uitleg van die Nuwe Testamentiese tekste beskou. Die gevolg van Bultmann se vertrekpunte is dat hy die Christologiese konstrukte van die Nuwe Testament as voorstellingsmatige objektiverings van die vroegste gelowiges se ontmoetings met God deur Jesus Christus verstaan wat deur die fantasieë van destyds bepaal is. Barth (1994:278) betwyfel dit of hierdie bedenklike vertrekpunte van Bultmann genoeg rede bied om hom as ketter te brandmerk of te bewys dat sy teologie nie versoenbaar met die kerklike belydenis is nie.

Barth (1994:282) meen die probleem wat op die tafel kom, is nie een wat alleen met Bultmann se teologie te make het nie, maar met die 'Fehlentwicklung einer ganzen theologischen Epoche.' Sy raad aan die kerk is dus om die groter probleem aan te spreek, of om die saak met rus te laat. Hy meen dit is nie duidelik of die kerk wel staan, waar die kerk behoort te staan wanneer sy Jesus as die opgestane Here bely nie (Barth 1994:284). Indien Bultmann se teologie werklik 'n gevaar vir die kerk sou inhou, kan die kerk alleen die gevaar die hoof bied deur Bultmann met ' $n$ lewendige gemeente te omring. Die kerk kan alleen haar geloof uitleef deur nie net teoreties nie, maar ook in die praktyk kerk te wees (Barth 1994:285).

\section{Slot}

Die fundamentele verskil tussen Barth en Bultmann se verstaan van Jesus se opstanding is nie dat Barth glo dat Jesus wel werklik opgestaan het, maar dat Bultmann dit nie glo nie. Die hermeneutiese vraag na die teenwoordigstelling (Vergegenwärtigung of repraesentatio) van Jesus Christus die opgestane Here en sy heilswerk in die geloof (Ebeling 1967:15) is vir albei die teoloë die sentrale vraagstuk van die Christologie en dit is ook op hierdie punt dat hulle radikaal van mekaar verskil. Barth meen om uit die probleem te kom deur die onderskeid wat hy tref tussen 'Historie' en 'Geschichte' in te span. Hoewel die geskiedenis van Jesus nie as historiese feit bewys kan word nie, beteken dit volgens 
Barth nie dat dit nie 'n gebeurtenis is wat in die geskiedenis afgespeel het en daarom vir die gelowiges toeganklik is nie. Bultmann meen dat hierdie benadering God en sy werk objektiveer en verstaan daarom dat geloof suiwer genade is wat ons van God ontvang, net soos wat God ook uit genade Jesus opgewek het en die boodskap van die opwekking uit genade laat aangekondig het. Barth is reg in sy waarneming dat die paradoks dat historiese gebeure die ewige begronding vir alle geloof is, 'n strukturele analogie het in die vraag na die teenwoordigheid van Christus by die viering van die nagmaal. Dit in ag genome, lyk dit of Bultmann se teologie eerder met die nagmaalsteologie van die Heidelbergse Kategismus vergelyk kan word as met die Roomse doktrine oor die misviering, soos wat Barth meen.

Barth en Bultmann het met 'n fundamentele en legitieme teologiese probleem geworstel. Dit blyk duidelik uit die feit dat die vraagstuk waaroor dit hier gaan steeds op die agenda van enige ernstige teoloog is. Om net twee voorbeelde te noem: Pannenberg (1991:393) span die konsep van prolepsis in om na 'n bevredigende oplossing vir die probleem te soek en Moltmann (1989:237-296) beskryf die opstanding as eskatologiese gebeure in 'n poging om met die paradoks wat ter sprake is in die reine te kom. Duidelik staan Pannenberg nader aan Barth en Moltmann weer nader aan Bultmann. Dit blyk dat sommige gelowiges en selfs ook sommige predikante in die Nederduitsch Hervormde Kerk van Afrika nie altyd begryp wat die essensiële problematiek is wat ter sprake kom by die interpretasie van Jesus se opstanding nie. Mag Barth en Bultmann ons leer om met alle erns na die betekenis van die opstandingsboodskap te vra.

\section{Erkenning Mededingende belange}

Die outeur verklaar dat hy geen finansiële of persoonlike verbintenis het met enige party wat hom nadelig kon beïnvloed in die skryf van hierdie artikel.

\section{Literatuurverwysings}

Barth, K., 1948, Die Kirchliche Dogmatik, Band III/2: Die Lehre von der Schöpfung, Evangelischer Verlag, Zollikon-Zürich.

Barth, K., 1953, Die Kirchliche Dogmatik, Band IV/1: Die Lehre von der Versöhnung, Evangelischer Verlag, Zollikon-Zürich.

Barth, K., 1967, Das Glaubensbekenntnis der Kirche, EVZ-Verlag, Zürich.

Barth, K., 1975, Dogmatik im Grundriss, Evangelischer Verlag, Zollikon-Zürich.

Barth, K., 1977, Einführung in die evangelische Theologie, 2. Aufl., Gütersloher Verlagshaus Mohn, Gütersloh.

Barth, K., 1994, Karl Barth - Rudolf Bultmann Briefwechsel 1911-1966, 2. Aufl., Theologischer Verlag, Zürich.

Bultmann, R., 1952, 'Zum Problem der Entmythologisierung', in H-W. Bartsch (reds.), Kerygma und Mythos II, bl. 177-208, Herbert Reich, Hamburg.

Bultmann, R., 1960, 'Neues Testament und Mythologie. Das Problem der Entmythologisierung der neutestamentlichen Verkündigung', in H-W. Bartsch (reds.), Kerygma und Mythos I, 4. Aufl., bl. 15-48, Herbert Reich, Hamburg.

Bultmann, R., 1961, Theologie des Neuen Testaments, 4. Aufl., J.C.B. Mohr (Paul Siebeck), Tübingen.

Bultmann, R., 1965, Glauben und Verstehen: Gesammelte Aufsätze, Dritter Band, 3. Aufl., J.C.B. Mohr (Paul Siebeck), Tübingen.

Bultmann, R., 1967, Exegetica, Aufsätze zur Erforschung des Neuen Testaments, J.C.B. Mohr (Paul Siebeck), Tübingen.

Bultmann, R., 1968, Glauben und Verstehen, Gesammelte Aufsätze, Zweiter Band, 5. Aufl., J.C.B. Mohr (Paul Siebeck), Tübingen,

Bultmann, R., 1969, Die drei Johannesbriefe, 2. Aufl., Vandenhoeck \& Ruprecht, Göttingen.

Bultmann, R., 1975a, Glauben und Verstehen: Gesammelte Aufsätze, Vierter Band, 3. Aufl., J.C.B. Mohr (Paul Siebeck), Tübingen.

Bultmann, R., [1954-1955] [1962] 1975b, History and eschatology, 3rd edn., Edinburgh University Press, Edinburgh. (The Gifford Lectures).

Bultmann, R., 1976, Der zweite Brief an die Korinther, Vandenhoeck \& Ruprecht, Göttingen.

Bultmann, R., 1977, Jesus, 3. Aufalge, Gütersloher Verlagshaus Mohn, Gütersloh. PMid:844390

Bultmann. R., 1978, Das Evangelium des Johannes, 20. Aufl., Vandenhoeck \& Ruprecht, Göttingen.

Bultmann, R., 1980, Glauben und Verstehen: Gesammelte Aufsätze, Erster Band, 8. Aufl., J.C.B. Mohr (Paul Siebeck), Tübingen.

Ebeling, G., 1967, 'Die Bedeutung der historisch-kritischen Methode für die protestantische Theologie und Kirche', in G. Ebeling (reds.), Wort und Glaube, 3. Aufl., bl. 1-49, J.C.B. Mohr (Paul Siebeck), Tübingen.

Jüngel, E., 1982, Barth-Studien, Benziger Verlag, Zürich-Köln.

Lattke, M., 1984, Register zu Rudolf Bultmanns Glauben und Verstehen, Band I-IV, J.C.B. Mohr (Paul Siebeck), Tübingen.

Moltmann, J., 1989, Der Weg Jesu Christi: Christologie in messianischen Dimensionen, Kaiser Verlag, München.

Pannenberg, W., 1991, Systematische Theologie, Band 2, Vandenhoeck \& Ruprecht, Göttingen.

Schmithals, W., 1967, Die Theologie Rudolf Bultmanns, 2. Aufl., JCB Mohr (Paul Siebeck), Tübingen.

Weber, O., 1967, Karl Barths Kirchliche Dogmatik, 6. Aufl., Neukichener Verlag, Neukirchen-Vluyn. 